\title{
Quality of life in patients with acromegaly and the effect of
}

\section{somatostatin analogues}

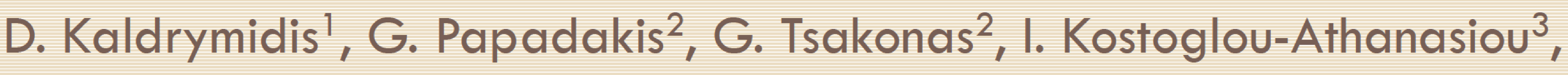 \\ P. Kaldrymidis' ${ }^{1}$ M. Peppa ${ }^{4}$, P. Roussou' ${ }^{1}$ E. Diamanti-Kandarakis ${ }^{1}$ \\ (1) 3rd Department of Internal Medicine, University of Athens, Sotiria General Hospital, Athens, Greece \\ (2) Department of Endocrinology, Metaxa Anticancer Hospital, Athens, Pireaus, Greece \\ (3) Department of Endocrinology, Red Cross Hospital, Athens, Greece

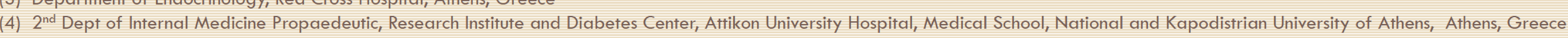

Objective. Quality of life is currently considered a major factor in the assessment of disease outcome. The aim was to assess quality of life in acromegaly and the effect of somatostatin analogues on it.

Design. This study included 101 patients with acromegaly, mean age $59.51 \pm 1.35$ years (mean \pm SEM), with a disease duration of $12.88 \pm 0.96$ years. All subjects completed the Acromegaly Quality of Life Questionnaire (AcroQoL) which is a disease-specific questionnaire for patients with acromegaly. It contains 22 questions with five possible responses. Each response is scored from 1 to 5 and the maximum score is 110 whereas the minimum score is 22. A group of 27 patients were treated initially with a somatostatin analogue s.c. in 3 divided daily doses and subsequently long acting somatostatin analogues, whereas 72 were treated with long acting somatostatin analogues as a primary medical treatment.

Results. Quality of life as assessed by AcroQol was found to be impaired in acromegaly. The administration of somatostatin analogues was found to improve quality of life in acromegaly. Acromegalics showed a mean total AcroQoL score of $53.22 \pm 1.87$ (mean \pm SEM) before treatment. Total AcroQol after treatment was $73.59 \pm 2.97$ for patients who initially received somatostatin analogues 3 times daily $(n=27)$, and $86.15 \pm 1.37$ for all the patients who received long acting somatostatin analogues once per 28 days $(27$ patients who first received short acting and 72 patients who received long acting somatostatin analogues as a primary treatment) $(p<0.001)$

Conclusions. Quality of life is impaired in acromegaly. The administration of somatostatin analogues is related with better quality of life. Long acting somatostatin analogues improve quality of life more than short acting somatostatin analogues.
Table 1. Descriptive characteristics of patients with acromegaly

\begin{tabular}{l|c|}
\hline Variable & Number of patients (n=101) \\
\hline Age (years \pm SEM) & $59.51 \pm 1.35$ \\
\hline Age at Diagnosis (years \pm SEM) & $46.63 \pm 1.31$ \\
\hline Males / females & $45 / 56$ \\
\hline Micro/macroadenoma & 38 / 63 \\
\hline $\begin{array}{l}\text { Surgical therapy } \\
\text { Radiotherapy }\end{array}$ & 79 \\
\hline $\begin{array}{l}\text { Medical therapy } \\
\text { Somatostatin analogues initially and } \\
\text { then long acting somatostatin }\end{array}$ & 99 \\
analogues & 27 \\
Long acting somatostatin analogues & \\
Hypertension & 72 \\
Cardiovascular disease & 52 \\
Diabetes Mellitus & 15 \\
Malignancies & 51
\end{tabular}

Table 2. AcroQol scores (mean \pm SEM) in patients with acromegaly before and after treatment with short acting and long acting somatostatin analogues, Student's t test

\begin{tabular}{|c|c|c|c|c|}
\hline Variable & $\begin{array}{l}\text { Before } \\
\text { Treatment }\end{array}$ & $\begin{array}{l}\text { After } \\
\text { Treatment } \\
\text { with } \\
\text { SSAx3/day } \\
\text { n=27 }\end{array}$ & $\begin{array}{l}\text { After } \\
\text { Treatment } \\
\text { with long } \\
\text { acting SSA } \\
\text { once/28 days } \\
\text { n= } 99\end{array}$ & Significance \\
\hline $\begin{array}{l}\text { AcroTot } \\
(\min 22-\max 110)\end{array}$ & $53.22 \pm 1.87$ & $\begin{array}{l}73.59 \pm \\
2.97\end{array}$ & $86.15 \pm 1.37$ & $p<0.001$ \\
\hline $\begin{array}{l}\text { AcroPsy } \\
(\min 14-\max 70)\end{array}$ & $35.44 \pm 1.26$ & $\begin{array}{l}47.56 \pm \\
2.03\end{array}$ & $54.98 \pm 0.95$ & $p<0.001$ \\
\hline $\begin{array}{l}\text { AcroApp } \\
(\min 7-\max 35)\end{array}$ & $13.86 \pm 0.61$ & $\begin{array}{l}21.63 \pm \\
1.01\end{array}$ & $25.95 \pm 0.54$ & $p<0.001$ \\
\hline $\begin{array}{l}\text { AcroRel } \\
(\min 7-\max 35)\end{array}$ & $21.43 \pm 0.75$ & $\begin{array}{l}25.93 \pm \\
1.23\end{array}$ & $29.37 \pm 0.52$ & $p<0.001$ \\
\hline $\begin{array}{l}\text { AcroPhy } \\
\text { (min 8-max 40) }\end{array}$ & $18.17 \pm 0.77$ & $\begin{array}{l}25.78 \pm \\
1.24\end{array}$ & $30.93 \pm 0.58$ & $p<0.001$ \\
\hline
\end{tabular}

